\title{
Use of a Combination of Vertical and Horizontal Boreholes in Massive Blasting of Benches in the Surface Quarry Rodež
}

\author{
Uporaba kombinacije vertikalnih in horizontalnih vrtin pri \\ masovnem miniranju etaž na površinskem kamnolomu Rodež
}

\author{
Matija Tori*, Stanojle Vajović, Niko Goleš, Elvir Muhić, Miha Peternel \\ IRGO - Institute for Mining, Geotechnology and Environment, Slovenčeva 93, 1000 Ljubljana \\ *matija.tori@irgo.si
}

\begin{abstract}
This article deals with the extraction of minerals (limestone/marl/flysch) in the quarry Rodež, which is located in western Slovenia. During the extraction of minerals in a quarry, drilling and blasting of benches are used. The focus of the article is on the analysis of the parameters related to drilling and blasting in surface excavations when using a combination of explosions and introducing horizontal wells along with vertical holes in the bench. On the basis of the analysis of basic parameters through a combination of drilling horizontal wells and charging those with the ammonal + Anfex explosive, analyses of effects of seismic disturbances on potentially affected buildings have also been conducted. The article is connected to and deals exclusively with the basic parameters of drilling and blasting, with the introduction of horizontal drilling and with the analysis of seismic measurements of threatened buildings in accordance with the German standard German Institute for Standardisation (DIN) 4150 during the use of a new method of blasting.
\end{abstract}

Key words: quarry, blasting, seismic measurements, DIN 4150

\section{Povzetek}

Članek obravnava pridobivanje mineralne surovine (apnenec/lapor/fliš) v kamnolomu Rodež, ki se nahaja na območju zahodne Slovenije. Pri pridobivanju mineralnih surovin $\mathrm{v}$ kamnolomu se uporablja standardna tehnologija z vrtanjem in miniranjem po etažah. Poudarek v članku je na analizi parametrov vrtanja in razstreljevanja v površinskem kopu pri uporabi kombinacije razstreliv in uvedbi nove geometrije horizontalnih vrtin skupaj z vertikalnimi vrtinami na etaži. Na osnovi analize osnovnih parametrov s kombinacijo vrtanja horizontalnih vrtin in njihovega polnjenja z razstrelivi AMONAL + ANFEX so bile opravljene tudi analize seizmičnih vplivov na potencialno ogrožene objekte. V članku se navezujemo in obravnavamo izključno osnovne parametre vrtanja in miniranja z uvedbo nove geometrije horizontalnih vrtin ter analizo meritev seizmičnih vibracij z vplivi na ogrožene objekte po nemškem standardu DIN 4150 pri uporabi nove metode miniranja.

Ključne besede: kamnolom, miniranje, seizmične meritve, DIN 4150 


\section{Introduction}

Extraction of minerals through open-cast mining is, along with other methods of extraction, enabled by the technology of mining or blasting of compact rock masses.

In this article, we focus on the analysis of blasting during surface excavation in the quarry Rodež at Anhovo, where the method of obtaining minerals through the extraction technique of blasting the blasting fields by benches is used. The analysis takes into account two examples with a different number and geometry of blasting boreholes. The first example deals with the charging of blasting boreholes for two lines of 'vertical' and one line of 'horizontal' boreholes; the second example deals with the charging of blasting boreholes for one line of 'vertical' and one line of 'horizontal' boreholes.

Initially, the geometry of vertical boreholes was used almost exclusively for mineral extraction through blasting in the quarry Rodež. This created certain problems, such as, e.g. an uncontrolled granulation of the diggings and a deformed geometry of the lower bench (the fifth one). The methodology of blasting was upgraded with the addition of additional horizontal boreholes on the fifth bench, which resulted in a significant improvement and an update of the method of extraction of the mineral material, as well as resulting in a flat lower bench plain or, in other words, a plain without protrusions.

When blasting with vertical boreholes, two combinations of explosives were used: 1: Kamex-C (cartridges); 2: combination of ammonal (cartridges) and Anfex (bulk packaging) [1].

The analyses of measurements and the theoretical knowledge of the demolition techniques established that extraction using the first combination of explosives (Kamex-C + ammonal) in the 'leg' of the bench resulted in moving closer to the necessary concentration of energy and that the careful preparation of the blasting field resulted in a successful blast without the use of the auxiliary 'horizontal' blasting boreholes. Additionally, in the upper parts, the intended charging with the ammonal explosive was in surplus, which allowed the reduction of the specific consumption of explosives and also the reduction of the borehole diameter from $d_{\mathrm{v}}=105 \mathrm{~mm}$ to $d_{\mathrm{v}}=95 \mathrm{~mm}[1]$.
With the second combination of explosives (ammonal + Anfex), it was obvious that the necessary concentration of the explosive charge in the toe of the bench cannot be reached only by using 'vertical' boreholes. The deficit was such that when blasting, the 'legs' remained intact, which caused serious problems when working on the surface excavation. Thus, charging the upper parts of the blasting boreholes with Anfex got closer to the theoretically necessary charges.

Through the economic analysis and the cost optimisation of blasting, it was found that the use of the non-cartridge explosive was more optimal, because the second combination of explosives with additionally improved method of blasting with horizontal boreholes produced better results.

\section{Analysis of the construction of vertical and additional horizontal boreholes}

Because of the problems caused by the use of combinations of explosives and the geometry of drilling, an additional solution had to be found. Analysis of the problems that occur as a result of blasting with two basic combinations Kamex-C + ammonal and ammonal + Anfex and without constructing additional horizontal boreholes is shown in Figure 1, which graphically presents the difficulties encountered.

On the basis of the technological procedures and theoretical knowledge, calculations for an additional execution of horizontal boreholes in the toe of the bench were made. By introducing horizontal boreholes, the technical problems were solved, and the geometry of the blasting field did not change significantly; the diameter of the vertical borehole $\left(d_{v}=95 \mathrm{~mm}\right)$ remained the same and the diameter of the horizontal borehole was $d_{\mathrm{h}}=90 \mathrm{~mm}$.

During the entirety of the procedure, the use of the second combination of explosives (ammonal + Anfex) was also taken into account. Technical solutions should also consider that the specific consumption does not change considerably, regardless of the basic or previous type of blasting. 


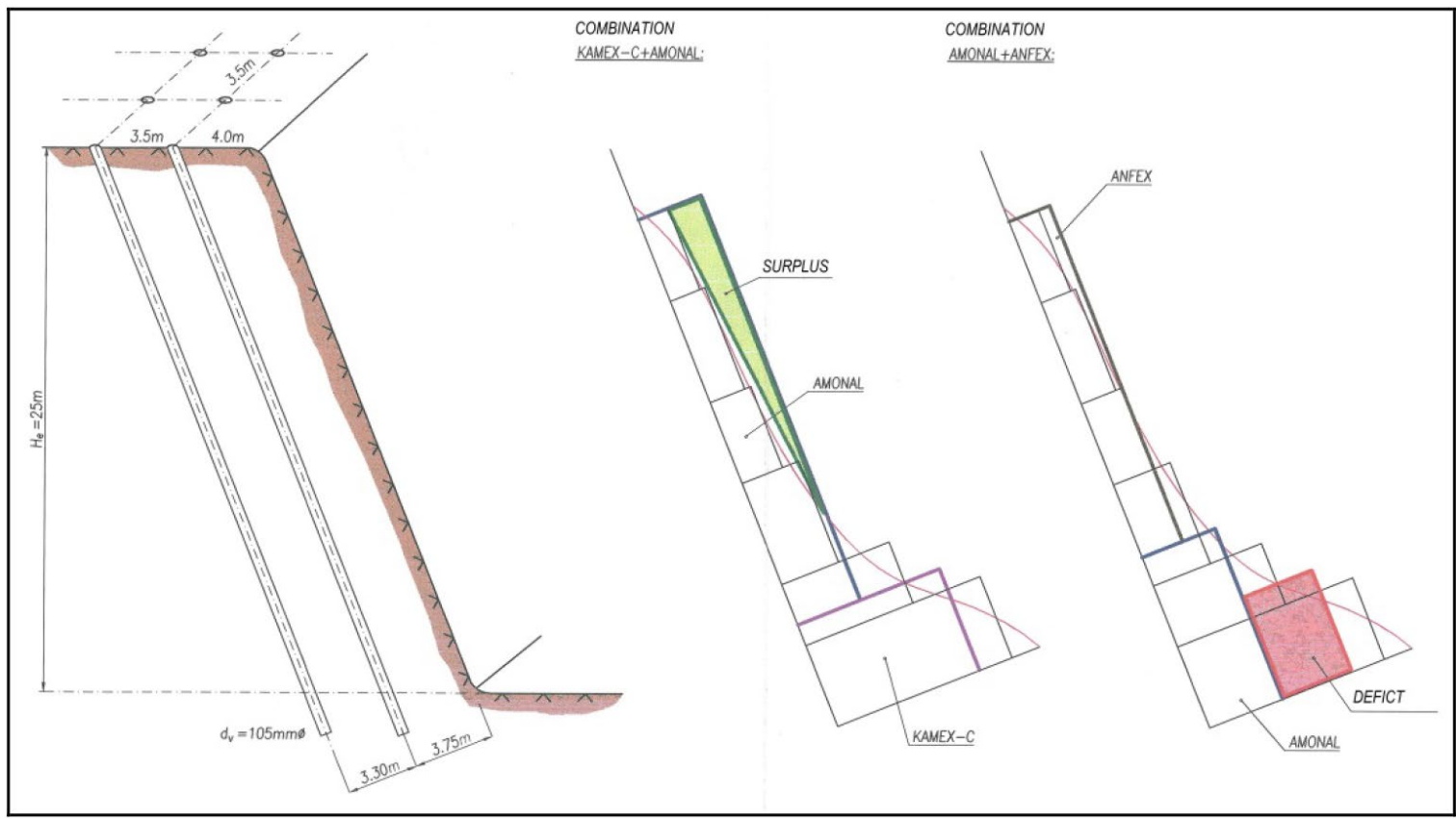

Figure 1: A graphical representation of problems that have occurred when using a combination of charges in exclusively vertical boreholes [1].

As part of finding the solution, a new construction of the explosion charge of the vertical blasting boreholes was produced, which takes advantage of the additional horizontal boreholes. This construction is relevant for both the vertical boreholes in two rows and the horizontal boreholes in one row. When constructing the explosive charges of the blasting field, the charges are distributed on the basis of the various heights of the benches $\left(H_{\mathrm{e}}=25 \mathrm{~m}, H_{\mathrm{e}}=20 \mathrm{~m}\right.$ and $H_{\mathrm{e}}=10 \mathrm{~m}$ ) for both one and two rows of vertical boreholes on the bench, as well as on the basis of greater density in the horizontal boreholes.

The depth and slope of the working bench had to be determined in relation to the depth and slope of the boreholes. Figure 2 illustrates a construction that uses two rows of vertical boreholes and one row of horizontal borehole. The length of the horizontal borehole in the toe of the bench had to be determined, and this length depends on whether blasting boreholes with one or two rows are used. Basic information about the lengths is given in Tables 1 and 2 . Vertical boreholes on the bench are $0.8 \mathrm{~m}$ deeper than the necessary depth of the boreholes with the purpose of explosive charging. This part of the boreholes is called 'the borehole

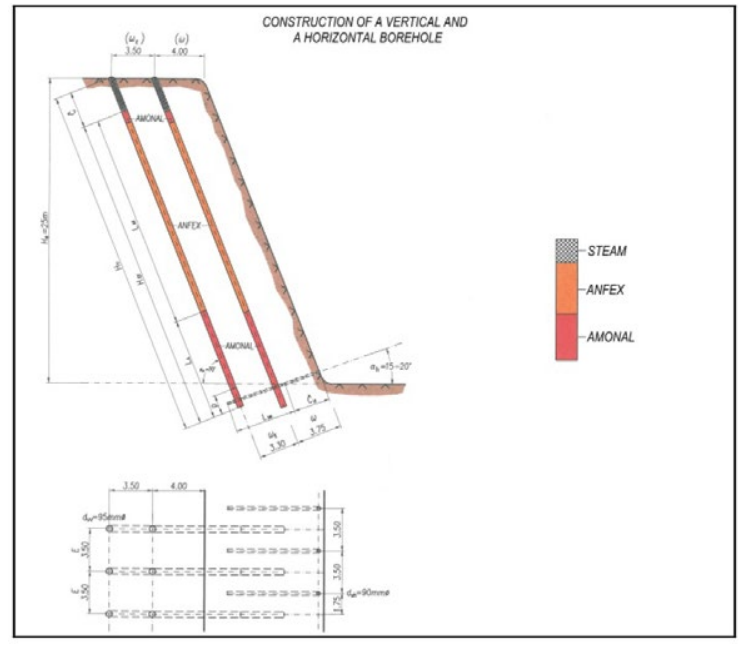

Figure 2: Construction of a vertical and a horizontal borehole [1].

loss' as $3 \%-15 \%$ of the borehole length $(5 \%$ on average) normally collapses or is backfilled after drilling. 'Horizontal' boreholes are longer by $0.4 \mathrm{~m}$, which is represented in Figure 3, which shows the construction of horizontal boreholes. The length of the plug is $20-30$ times the diameter of the borehole, which means that the borehole plug is $3.0 \mathrm{~m}$, both in the case of the horizontal and the vertical boreholes. The plug is made of clay or of drilled material. 


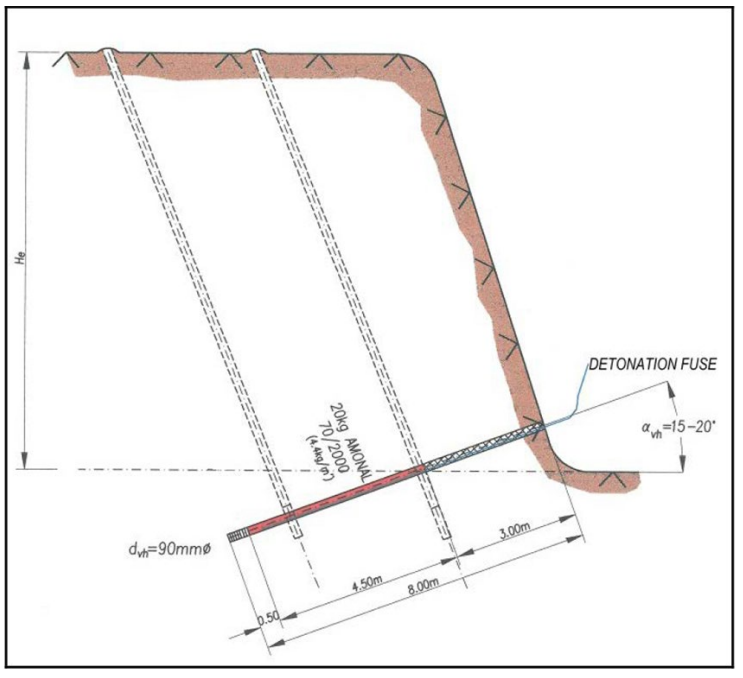

Figure 3: Construction of the explosion charge of 'horizontal' blasting boreholes [1].

Each of the 'vertical' blasting boreholes is equipped with two detonation fuses, which enable a more secure injection of the total amount of explosives in the blasting boreholes. In all of the cases of different bench depths $(10 \mathrm{~m}$, $20 \mathrm{~m}$ and $25 \mathrm{~m}$ ), one of the detonation fuses runs throughout the filled length of the blasting borehole and the second one runs all the way to the last (upper) cartridge just under the plug. Ammonal-V charge with cartridge diameter of $700 \mathrm{~mm}$ and weight of $2000 \mathrm{~g}$ was used.

In the cases of longer blasting boreholes $\left(H_{\mathrm{e}}=25 \mathrm{~m}\right)$, an interim charging with the ammonal charge (when filling the borehole with Anfex, which is poured directly into the blasting borehole) is recommended for achieving better results. Adding the ammonal explosive is especially important if the blasting boreholes are damp. Even though the cartridge version of the ammonal-V (water resistant) explosive is used, where cartridges use polyethylene packaging, the damp causes the explosive to lose sensitivity and effectiveness of its functioning. Therefore, charging the blasting borehole must be done quickly and together with charging of the 'dry' boreholes.

Charging the boreholes with ammonal and Anfex explosive charge is used when the quantity of the explosive per metre of the borehole (in kilograms per metre) is calculated. Calculation of the necessary quantity is based on a specific formula for each explosive: a) Ammonal:

$q_{\text {linA }}=\frac{d \frac{2}{p}}{4} \times \pi \times \gamma_{e x} \times K_{p}=\frac{0.702^{2}}{4} \times 3.14 \times$

$\times 1.05 \times(1.1$ to 1.15$) \times 10=$

$=4.4$ to $4.6\left[\mathrm{~kg} / \mathrm{m}^{\prime}\right] ;[1]$

The following is of importance:

- for vertical blasting boreholes, $q_{\operatorname{linA}}=4.5 \mathrm{~kg} / \mathrm{m}^{\prime}$ is accepted;

- for horizontal blasting boreholes, $q_{\text {linAH }}=4.4 \mathrm{~kg} / \mathrm{m}^{\prime}$ is accepted.

b) Anfex:

It is used only in vertical blasting boreholes [1]:

$$
q_{\text {linAX }}=\frac{d \frac{2}{v}}{4} \times \pi \times \gamma_{e x} \times K_{p}=\frac{0,95^{2}}{4} \times 3,14 \times
$$

$\times 0,75 \times 1,0 \times 10=5,3\left[\mathrm{~kg} / \mathrm{m}^{\prime}\right][1]$

\section{Meaning of the designations used:}

$q_{\text {linAX }} \ldots$. charge density of the explosive Anfex $\left(\mathrm{kg} / \mathrm{m}^{\prime}\right)$.

$q_{\operatorname{linA}} \ldots$ charge density of the explosive ammonal $\left(\mathrm{kg} / \mathrm{m}^{\prime}\right)$.

$d_{\mathrm{p}}$... diameter of cartridge of the explosive (m)

$d_{\mathrm{v}}$.... diameter of blasting boreholes $(\mathrm{m})$

$\mathrm{g}_{\text {ex }} \ldots$ density of the explosive $\left(\mathrm{kg} / \mathrm{m}^{3}\right)$

$\mathrm{K}_{\mathrm{p}}$... coefficient of charging

Let us take blasting in the cases of two rows of vertical boreholes (Figure 2) and one row of horizontal boreholes (Figure 3), with the bench being $25 \mathrm{~m}$ in height [1].

The length of the charge for the vertical borehole charged with the ammonal explosive is $10.6 \mathrm{~m}$, with a calculated consumption of explosive of $4.5 \mathrm{~kg} / \mathrm{m}$. The remainder of the vertical borehole is charged with Anfex explosive. The necessary length of the charge is $14.2 \mathrm{~m}$ and the consumption is $5.3 \mathrm{~kg} / \mathrm{m}^{\prime}$, which amounts to $75 \mathrm{~kg}$ of the Anfex explosive necessary for charging one vertical borehole.

For the purposes of charging the horizontal borehole, the length of the charge with ammonal explosive is $4.5 \mathrm{~m}$ and the consumption is 
Table 1: Basic parameters and norms of massive blasting in the case of two rows of vertical and one row of horizontal blasting boreholes [1].

\begin{tabular}{|c|c|c|c|}
\hline \multirow{2}{*}{ Data } & \multicolumn{3}{|c|}{ Bench height $H_{\mathrm{e}}(\mathrm{m})$} \\
\hline & 25 & 20 & 10 \\
\hline $\boldsymbol{d}_{\mathrm{vv}} / \boldsymbol{d}_{\mathrm{vh}}(\mathrm{mm})$ & \multicolumn{3}{|c|}{$95 / 90$} \\
\hline$\check{C}(\mathrm{~m})$ & \multicolumn{3}{|c|}{3.0} \\
\hline $\boldsymbol{H}_{\mathrm{vv}}(\mathrm{m})$ & 28.6 & 23.3 & 12.6 \\
\hline $\boldsymbol{H}_{\mathrm{vh}}(\mathrm{m})$ & \multicolumn{3}{|c|}{8.0} \\
\hline$\alpha_{\mathrm{vv}}\left({ }^{\circ}\right)$ & \multicolumn{3}{|c|}{70} \\
\hline$\alpha_{\mathrm{vh}}\left({ }^{\circ}\right)$ & \multicolumn{3}{|c|}{$15-20$} \\
\hline $\boldsymbol{W}(\mathrm{m})$ & \multicolumn{3}{|c|}{3.75} \\
\hline$(\boldsymbol{W})(\mathrm{m})$ & \multicolumn{3}{|c|}{4.0} \\
\hline $\boldsymbol{W}_{\mathrm{E}}(\mathrm{m})$ & \multicolumn{3}{|c|}{3.3} \\
\hline$\left(W_{\mathrm{E}}\right)(\mathrm{m})$ & \multicolumn{3}{|c|}{3.5} \\
\hline $\boldsymbol{E}(\mathrm{m})$ & \multicolumn{3}{|c|}{3.5} \\
\hline$Q=\left((W)+\left(W_{\mathrm{E}}\right)\right) \times E \times H_{\mathrm{e}}\left(\mathrm{m}^{3}\right)$ & 656.25 & 525 & 262.5 \\
\hline $\boldsymbol{L}_{\mathrm{A}}(\mathbf{k g})$ ammonal for 2 vertical and 1 horizontal borehole & 116 & 96 & 56 \\
\hline$L_{\text {Ax }}(\mathbf{k g})$ Anfex for 2 vertical boreholes & 150 & 116 & 38 \\
\hline$q\left(\mathrm{~kg} / \mathrm{m}^{3}\right)$ & 0.405 & 0.404 & 0.358 \\
\hline
\end{tabular}

$4.4 \mathrm{~kg} / \mathrm{m}$ ', which amounts to $20 \mathrm{~kg}$ of the explosive in one horizontal borehole.

For blasting two vertical and one horizontal boreholes, we need, in total, $116 \mathrm{~kg}$ of ammonal explosive and $150 \mathrm{~kg}$ of Anfex explosive. With two 'vertical' and one 'horizontal' borehole on the bench of $H_{\mathrm{e}}=25 \mathrm{~m}$, the following quantity of mineral material will be collapsed:

$Q=7.5 \times 3.5 \times 25=656.25 \mathrm{~m}^{3}[1]$

The consumption of explosive in two 'vertical' and one 'horizontal' borehole is $266 \mathrm{~kg}$, which means that the calculation-specific consumption of explosive is

$q=266 \mathrm{~kg} / 656.25 \mathrm{~m}^{3}=0.405 \mathrm{~kg} / \mathrm{m}^{3}[1]$

\section{Meaning of the designations used:}

$Q$... blast volume for two 'vertical' and one 'horizontal' borehole (in cubic metres)

$q$... specific consumption of explosive (in kilograms per cubic metre)
With this, we move closer to the basic theoretical expectations of explosive energy distribution along the slope of the bench and to the desired specific consumption of explosive $q=0.400 \mathrm{~kg} / \mathrm{m}^{3}$.

In this example, we present the quantity of explosive necessary for the blast in two vertical and one horizontal borehole, with the height of the bench being $25 \mathrm{~m}$. In Tables 1 and 2, the basic parameters of blasting the remainder of the height of the benches are presented, both for the two-row and one-row charging processes of the vertical boreholes.

In Table 1, we find an overview of the basic parameters of blasting and also the basic norms for the examples of various heights of benches $H_{\mathrm{e}}=10-25 \mathrm{~m}$, when using three boreholes: two vertical and one horizontal.

Meaning of the designations used:

$d_{\mathrm{vv} . . .}$ diameter of 'vertical' blasting boreholes (mm)

$\check{C}$... steam height $(\mathrm{m})$ 
Table 2: Basic parameters and norms of massive blasting with one row of 'vertical' and one row of 'horizontal' blasting boreholes [1].

\begin{tabular}{|c|c|c|c|}
\hline \multirow{2}{*}{ Data } & \multicolumn{3}{|c|}{ Bench height $H_{\mathrm{e}}(\mathrm{m})$} \\
\hline & 25 & 20 & 10 \\
\hline $\boldsymbol{d}_{\mathrm{vv}} / \boldsymbol{d}_{\mathrm{vh}}(\mathrm{mm})$ & \multicolumn{3}{|c|}{$95 / 90$} \\
\hline$\check{\boldsymbol{C}}(\mathrm{m})$ & \multicolumn{3}{|c|}{3.0} \\
\hline $\boldsymbol{H}_{\mathrm{vh}}(\mathrm{m})$ & 24.8 & 19.8 & 9.0 \\
\hline $\boldsymbol{H}_{\mathrm{vh}}(\mathrm{m})$ & \multicolumn{3}{|c|}{4.8} \\
\hline$\alpha_{\mathrm{vv}}\left({ }^{\circ}\right)$ & \multicolumn{3}{|c|}{70} \\
\hline$\alpha_{\mathrm{vh}}\left({ }^{\circ}\right)$ & \multicolumn{3}{|c|}{20} \\
\hline $\boldsymbol{W}(\mathrm{m})$ & \multicolumn{3}{|c|}{3.75} \\
\hline$(\boldsymbol{W})(\mathrm{m})$ & \multicolumn{3}{|c|}{4.0} \\
\hline $\boldsymbol{E}(\mathrm{m})$ & \multicolumn{3}{|c|}{3.5} \\
\hline $\boldsymbol{E}_{\mathrm{h}}(\mathrm{m})$ & \multicolumn{3}{|c|}{1.75} \\
\hline $\boldsymbol{Q}=(\boldsymbol{W}) \times \boldsymbol{E} \times \boldsymbol{H}_{\mathrm{e}}\left(\mathrm{m}^{3}\right)$ & 350 & 280 & 140 \\
\hline$L_{\mathrm{A}}(\mathrm{kg})$ ammonal for 1 vertical borehole and 1 horizontal. borehole & 24 & 24 & 24 \\
\hline$L_{\mathrm{Ax}}(\mathrm{kg})$ Anfex for 1 vertical borehole & 97 & 71 & 16 \\
\hline $\mathrm{q}(\mathrm{kg} / \mathrm{m} 3)$ & 0.346 & 0.339 & 0.286 \\
\hline
\end{tabular}

$H_{\mathrm{vv} .} \ldots$ drilling depth of 'vertical' blasting boreholes (m)

$\alpha_{\mathrm{vv}} \ldots$ incline (relative to a horizontal) of 'vertical' blasting boreholes is equal to the incline of the bench slope $\left({ }^{\circ}\right)$

$W . .$. 'burden' in the first row of blasting boreholes (m)

$(W) . .$. 'burden' as measured on the platform of the bench in the first row of the blasting boreholes (m)

$W_{\mathrm{E} . .}$ 'burden' in the second row of blasting boreholes (m)

$\left(W_{\mathrm{E}}\right) \ldots$. 'burden' as measured on the platform of the bench in the second row of the blasting boreholes (m)

$E$... distance between rows of vertical blasting boreholes in the same row $(\mathrm{m})$

$Q \ldots$ volume of the rock collapsed because of the blasting charge $\left(\mathrm{m}^{3}\right)$

$q \ldots$ specific consumption of explosive $\left(\mathrm{kg} / \mathrm{m}^{3}\right)$

$L_{\mathrm{A}^{\prime}}$.. explosive charge of ammonal $(\mathrm{kg})$
When constructing vertical boreholes in one row with additional horizontal boreholes, the geometry of drilling is denser than in the case of a blasting field with two rows of vertical boreholes. The distance between two rows of horizontal boreholes is shorter by half of the distance between vertical boreholes. In the lower part of Figure 4, there is a schematic display of vertical and horizontal boreholes in the case of one-row vertical boreholes.

In Table 2, a summary of the parameters of blasting in the case of equal bench heights is demonstrated, namely one row of vertical and one row of horizontal boreholes in the toe of the bench, where the spacing between horizontal boreholes is half of the distance between vertical boreholes.

\section{Meaning of the designations used:}

$d_{\mathrm{vv}} \ldots$ diameter of 'vertical' blasting boreholes (mm) 


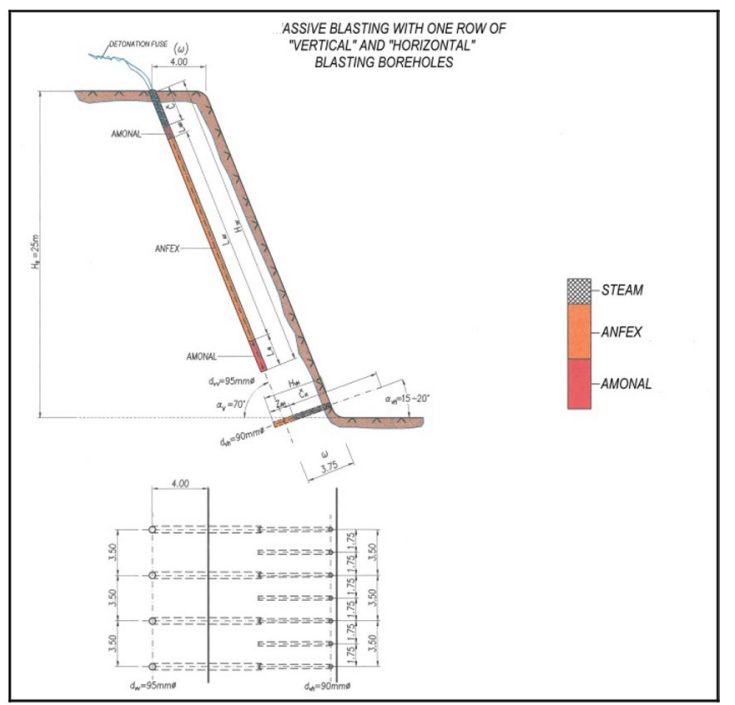

Figure 4: Massive blasting with one row of 'vertical' and 'horizontal' blasting boreholes [1].

$\check{C}$... steam height $(\mathrm{m})$

$d_{\mathrm{vh} \text { '.. }}$ diameter of 'horizontal' blasting boreholes $(\mathrm{mm})$

$H_{\mathrm{vv}} \ldots$ drilling depth of 'vertical' blasting boreholes (m)

$H_{\mathrm{vh}}$.. drilling depth of 'horizontal' blasting boreholes (m)

$a_{\mathrm{vv}}$... incline (relative to a horizontal) of 'vertical' blasting boreholes is equal to the incline of the bench slope $\left({ }^{\circ}\right)$

$\mathrm{a}_{\mathrm{vh}}$... incline (relative to a horizontal) of 'horizontal' blasting boreholes $\left({ }^{\circ}\right)$

$W .$. 'burden' in the first row of blasting boreholes $(\mathrm{m})$

$(W) . .$. 'burden' as measured on the platform of the bench in the first row of the blasting boreholes $(\mathrm{m})$

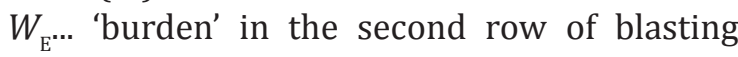
boreholes (m)

$\left(W_{\mathrm{E}}\right) \ldots$ 'burden' as measured on the platform

of the bench in the second row of the blasting boreholes (m)

E... distance between rows of vertical blasting boreholes in the same row $(\mathrm{m})$

$E_{\mathrm{h}} \ldots$ distance between rows of horizontal blast-

ing boreholes in the same row (m)

$Q$... volume of the rock collapsed because of the blasting charge $\left(\mathrm{m}^{3}\right)$

q... specific consumption of explosive $\left(\mathrm{kg} / \mathrm{m}^{3}\right)$

$L_{A^{\prime} \ldots}$ explosive charge ammonal (kg)

$L_{\mathrm{AX}} \ldots$ explosive charge Anfex $(\mathrm{kg})$

\section{Analysis of seismic measurements in the case of blasting using the method of additional horizontal boreholes}

Ground vibration that affects the building or other structure depends mainly on the functioning of the explosion charge of the borehole located on the blasting field or, in other words, on the interval filling of the blasting field. Additional important information is the distance between the source of the vibration and the potentially affected structure.

In accordance with the basic parameters of blasting with a combination of vertical and horizontal boreholes and while using a combination of the explosives ammonal + Anfex in the quarry Rodež at Anhovo, continuous seismic measurements of structures potentially affected by the blasting procedure were carried out with the purpose of determination of the effects of blasting on structures by using the German standard German Institute for Standardisation (DIN) 4150 and Austrian standard ÖNORM S 9020.

Seismic measurements on the potentially affected structures in the direct vicinity of the quarry were consistently carried out during the blasting procedure in the quarry Rodež. During all the blasts, the measurements were carried out at the same monitoring points. This ensured a thorough analysis and determination of the effects of vibrations on the structures. Seismic measurement data was obtained from the reports of seismic measurements during the blasting procedure in the quarry Rodež [2-4].

In all of the blast analyses, combinations of various quantities of explosives for charging boreholes, number of boreholes and number of sorts of vertical boreholes and bindings are taken into account. In the analysis of seismic measurement results, we focus on residential and heritage protected structures, which are also potentially the most affected. Measurement values, taken during the individual blasts, showed that different quantities of explosives, numbers of boreholes and bindings resulted in different measured values of the amplitude of vibrations and their frequencies. The analysed values of seismic measurement, which are defined in the standard DIN 4150 [5], do not exceed the allowed limits of vibrations according 
Table 3: Basic information on the location of monitoring points, results of seismic measurements and basic parameters of blasting in the quarry Rodež [2-4].

\begin{tabular}{|c|c|c|c|c|c|c|c|c|c|}
\hline \multirow{3}{*}{$\begin{array}{l}\text { Measur- } \\
\text { ing point }\end{array}$} & \multirow{3}{*}{$\begin{array}{l}\text { Name of the } \\
\text { analysed } \\
\text { structure }\end{array}$} & \multicolumn{7}{|c|}{ SEISMIC MEASUREMENTS } & \multirow{3}{*}{$\begin{array}{c}\text { Allowed speed } \\
\text { of vibrations } \\
\text { at certain } \\
\text { frequencies } \\
\text { and classes of } \\
\text { structures } \\
\begin{array}{c}\text { (DIN 4150) ' } V \\
\text { (mm/s) }\end{array}\end{array}$} \\
\hline & & Distance & $\begin{array}{c}\text { Combined } \\
\text { charge } \\
\text { of the } \\
\text { blasting } \\
\text { field }\end{array}$ & $\begin{array}{l}\text { Charge } \\
\text { per } \\
\text { interval }\end{array}$ & $\begin{array}{l}\text { Number of } \\
\text { boreholes } \\
\text { (I. vertical/ } \\
\text { II. vertical/I. }\end{array}$ & $\begin{array}{l}\text { Measured } \\
\text { value of } \\
\text { vibrations }\end{array}$ & $\begin{array}{l}\text { Measured } \\
\text { frequency }\end{array}$ & $\begin{array}{c}\text { Class } \\
\text { of the } \\
\text { structure }\end{array}$ & \\
\hline & & $R(\mathbf{m})$ & $\Sigma L(\mathrm{~kg})$ & $L_{\text {imax }}(\mathrm{kg})$ & & $V_{\mathrm{R} \max }(\mathrm{mm} / \mathrm{s})$ & $f(\mathrm{~Hz})$ & $\begin{array}{c}\text { (DIN } \\
4150)\end{array}$ & \\
\hline \multicolumn{10}{|c|}{ SEISMIC MEASUREMENTS: 11 June 2003 at 13:59:00; blast 1: IV. bench (E-213) } \\
\hline$\left(M_{M}-1\right)$ & $\begin{array}{l}\text { IV. bench } k \cdot+ \\
213 m \text { quarry } \\
\text { Rodež }\end{array}$ & 215 & & & & $7.49 \mathrm{~mm} / \mathrm{s}$ & $17-28 \mathrm{~Hz}$ & $\begin{array}{l}\mathrm{L}_{1 \text { industrial }} \\
\text { buildings }\end{array}$ & $24.1-24.8$ \\
\hline$\left(M_{M}-2\right)$ & $\begin{array}{c}\text { Rodež } 10 \\
k+147.5 \mathrm{~m} \\
\text { (doorstep of the } \\
\text { basement) }\end{array}$ & 590 & & & & $1.39 \mathrm{~mm} / \mathrm{s}$ & $13-43 \mathrm{~Hz}$ & $\begin{array}{l}\mathrm{L}_{2 \text { residential }} \\
\text { buildings }\end{array}$ & $5.7-13.2$ \\
\hline$\left(M_{M}-3\right)$ & $\begin{array}{l}\text { Church of St. } \\
\text { Michael Gornje } \\
\text { Polje } k+147 \mathrm{~m} \\
\text { (doorstep of the } \\
\text { side entrance) }\end{array}$ & 980 & 1528 & 135.5 & $14 / 0 / 7$ & $0.40 \mathrm{~mm} / \mathrm{s}$ & $15-17 \mathrm{~Hz}$ & $\begin{array}{l}\mathrm{L}_{3 \text { heritage }} \\
\text { protected } \\
\text { buildings }\end{array}$ & $5.7-5.9$ \\
\hline$\left(M_{M}-4\right)$ & $\begin{array}{c}\text { Morsko 45 } \\
k .+154.7 m \\
\text { (foundation) }\end{array}$ & 1.117 & & & & $0.18 \mathrm{~mm} / \mathrm{s}$ & $13-43 \mathrm{~Hz}$ & $\begin{array}{l}\mathrm{L}_{2 \text { residential }} \\
\text { buildings }\end{array}$ & $5.8-13.2$ \\
\hline \multicolumn{10}{|c|}{ SEISMIC MEASUREMENTS: 3 October 2003 at 13:56:13; blast 2: IV. bench (E-213) } \\
\hline$\left(\mathrm{M}_{\mathrm{M}}-1\right)$ & $\begin{array}{l}\text { IV. bench } k .+ \\
213 m \text { quarry } \\
\text { Rodež }\end{array}$ & 330 & & & & $5.40 \mathrm{~mm} / \mathrm{s}$ & $14-15 \mathrm{~Hz}$ & $\mathrm{~L}_{1 \text { industrial }}$ & $22.1-22.5$ \\
\hline$\left(M_{M}-2\right)$ & $\begin{array}{c}\text { Rodež } 10 \\
k .+147.5 \mathrm{~m} \\
\text { (doorstep of the } \\
\text { basement) }\end{array}$ & 640 & & & & $0.94 \mathrm{~mm} / \mathrm{s}$ & $11-13 \mathrm{~Hz}$ & $\begin{array}{l}\mathrm{L}_{2 \text { residential }} \\
\text { buildings }\end{array}$ & $5.2-5.8$ \\
\hline$\left(M_{M}-3\right)$ & $\begin{array}{l}\text { Church of St. } \\
\text { Michael Gornje } \\
\text { Polje } k+147 \mathrm{~m} \\
\text { (doorstep of the } \\
\text { side entrance) }\end{array}$ & 885 & 1493 & 131.5 & $8 / 7 / 7$ & $0.38 \mathrm{~mm} / \mathrm{s}$ & $9-18 \mathrm{~Hz}$ & $\begin{array}{l}\mathrm{L}_{3 \text { heritage }} \\
\text { protected } \\
\text { buildings }\end{array}$ & $3-4.2$ \\
\hline$\left(M_{M}-4\right)$ & $\begin{array}{l}\text { Morsko 45 } \\
k .+154.7 m \\
\text { (foundation) }\end{array}$ & 1.090 & & & & $0.27 \mathrm{~mm} / \mathrm{s}$ & $11-30 \mathrm{~Hz}$ & $\begin{array}{l}\mathrm{L}_{2 \text { residential }} \\
\text { buildings }\end{array}$ & $5.2-10$ \\
\hline \multicolumn{10}{|c|}{ SEISMIC MEASUREMENTS: January $14^{\text {th }} 2004$ at $13: 56$; blast 3: IV. bench (E-213) } \\
\hline$\left(M_{M}-1\right)$ & $\begin{array}{l}\text { IV. bench } k .+ \\
213 \text { m quarry } \\
\text { Rodež }\end{array}$ & 153 & & & & $10.40 \mathrm{~mm} / \mathrm{s}$ & $17-39 \mathrm{~Hz}$ & $\begin{array}{l}\mathrm{L}_{1 \text { industrial }} \\
\text { buildings }\end{array}$ & $23.6-34.8$ \\
\hline$\left(M_{M}-2\right)$ & $\begin{array}{c}\text { Rodež } 10 \\
k+147.5 m \\
\text { (doorstep of the } \\
\text { basement) }\end{array}$ & 564 & & & & $1.08 \mathrm{~mm} / \mathrm{s}$ & $12-15 \mathrm{~Hz}$ & $\begin{array}{l}\mathrm{L}_{2 \text { residential }} \\
\text { buildings }\end{array}$ & $5.3-6.3$ \\
\hline$\left(M_{M}-3\right)$ & $\begin{array}{l}\text { Church of St. } \\
\text { Michael Gornje } \\
\text { Polje } k+147 m \\
\text { (doorstep of the } \\
\text { side entrance) }\end{array}$ & 1.020 & 2847 & 129.5 & $13 / 13 / 13$ & $0.98 \mathrm{~mm} / \mathrm{s}$ & $15-22 \mathrm{~Hz}$ & $\begin{array}{l}\mathrm{L}_{3 \text { heritage }} \\
\text { protected } \\
\text { buildings }\end{array}$ & $3.6-4.5$ \\
\hline$\left(M_{M}-4\right)$ & $\begin{array}{c}\text { Morsko 45 } \\
k .+154.7 m \\
\text { (foundation) }\end{array}$ & 1.269 & & & & $0.32 \mathrm{~mm} / \mathrm{s}$ & $9.7-11 \mathrm{~Hz}$ & $\begin{array}{l}\mathrm{L}_{2 \text { residential }} \\
\text { buildings }\end{array}$ & $4.8-5.2$ \\
\hline
\end{tabular}


to the class of the structure and the frequency of vibrations.

The speed of vibrations as measured at the individual monitoring points is, in specific cases of blasting, dependent on various influencing factors, such as distances from the blasting field, geological structure, location of the monitoring points, total quantity of explosives per interval, different bindings of the blasting field and so on.

From the results of measurements presented in Table 3, we can observe that for residential structures (Rodež 10 and Morsko 45), religious structures (cerkev Sv. Mihaela - Gornje Polje) and the quarry bench (E 213) on the days of 11 June 2003, 3 October 2003 and 14 January 2004 in the quarry Rodež at the bench E213, the speeds of waves $\left(V_{\text {Rmax }}\right.$ ) of vibrations that occurred because of the blasting were not exceeded. This finding is based on the German standard DIN 4150, which prescribes the allowed speeds of vibrations at certain frequencies for a specific sort (class) of structures. Using seismic measurements that measured blasting in the quarry Rodež, it was established that the measured blasting did not affect the stability of individual structures.

In the cases of the second and the third blasts, the amount of explosives per interval remained the same, although the difference in the total quantity of explosive and the number of mining boreholes per individual minefield almost doubled. This is evident from the data in Table 3 for the individual minefields and blasts. The measured values of the vibrations remained, in both cases, basically the same. From this, we can conclude that the magnitude of vibration is significantly affected by the quantity of explosives that is triggered pet interval and not by the total quantity of explosive or the number of mining boreholes in the minefield.

Based on the analysis and the measurement results, we can conclude that the ground vibrations produced by the blasts did not produce effects that could cause damage or other changes of the analysed structures.

\section{Summary and conclusion}

With reference to the existing conditions, required safety, economic efficiency and environmental impact, the technical solutions achieve efficiency in terms of the parameters of the technology of execution of the drilling and blasting work. The advantages of such solutions are a minimal norm of drilling and a specific consumption of explosives, a reliable discharge of the lower part of the 'leg' of the foot, a more favourable ratio of ammonal: Anfex explosives and minimal quake effects. With the implementation of horizontal boreholes, a lot of attention has to be paid to their plugging, which can, in the case of insufficient plugging, increase the danger of an uncontrolled blast from the horizontal blasting boreholes.

A planned massive blasting anticipates a combined geometry of blasting fields with vertical and horizontal boreholes, as well as a combination of charging the blasting boreholes with different sorts of explosives for various heights of benches $\left(H_{\mathrm{e}}=10 \mathrm{~m}, H_{\mathrm{e}}=20 \mathrm{~m}\right.$ and $\left.H_{\mathrm{e}}=25 \mathrm{~m}\right)$. A new construction of charging the blasting boreholes and of bindings, as well as a time delay in regard to the direction of the opening is also planned. Based on the solutions, safe distances in relation to the charges in the millisecond interval, entire charging of the blasting field and the degree of vulnerability of buildings are determined in accordance with standards ONORM S 9020 [6] in DIN 4150 [5].

Based on the analysis of seismic measurements, which were made during the massive blasting using vertical and horizontal boreholes and with charging the boreholes with the ammonal + Anfex explosive, we can conclude that the performed blasts did not influence the analysed structures to the degree that they would cause damage or other changes to the nearby structures. Measured values of the velocity of oscillation are lower than the permitted maximum levels that are valid for the most sensitive class of structures $\mathrm{L}_{3}$ - heritage protected buildings (DIN 4150). 


\section{References}

[1] Določitev parametrov za vrtanje in odstreljevanje $\mathrm{v}$ površinskih kopih Rodež in Perunk, no. ip.: 1031-98/0.1/VS, Inštitut za rudarstvo, geotehnologijo in okolje.

[2] Poročilo o miniranju in seizmičnih meritvah z dne 11. junija 2003 v kamnolomu Rodež na 4. etaži (E-213), no. ip.: 355/2003-VS, Inštitut za rudarstvo, geotehnologijo in okolje.

[3] Poročilo o miniranju in seizmičnih meritvah z dne 3. oktobra 2003 v kamnolomu Rodež na 4. etaži (E-213), no. ip.: 500/2003-VS, Inštitut za rudarstvo, geotehnologijo in okolje.

[4] Poročilo o miniranju in seizmičnih meritvah z dne 14. januarja 2004 v kamnolomu Rodež na etaži E-213, no. ip.: 58/2004-VS, Inštitut za rudarstvo, geotehnologijo in okolje.

[5] DIN 4150-1; Vibrations in buildings - Part 1: Prediction of vibrations parameter.

[6] ÖNORM S 9020; Vibration protection for buried and surface facilities. 